\title{
Comparison of Physical, Chemical and Biological Soil Properties under Norway Spruce, European Beech and Sessile Oak - a Case Study
}

\author{
Bálint HEIL * Dávid HEILIG - Gábor KovÁcS \\ Institute of Environmental and Earth Sciences, Faculty of Forestry, University of Sopron, Sopron, Hungary
}

\begin{abstract}
This study examined the interaction of tree species and soil development in litter and the 0-10 cm mineral topsoil layer in European beech, Norway spruce, and sessile oak forests. It also compared the main soil chemical, physical, and selected microbiological indicators as well as the microbial biomass, basal and substrate induced respiration, lipid phosphate content, phospholipid fatty acid profiles (PLFA), and respiratory quinones (RQ). With Norway spruce, soil $\mathrm{pH}$, clay, and silt content were significantly lower, while exchangeable acidity was higher. This leads to a major loss of exchangeable cations of the upper soil layer resulting in lower base saturation. The microbial metabolic activity and microbial biomass of deciduous forest soils were significantly higher. The respiratory quotient (q) was highest in spruce, indicating disadvantageous circumstances for microbial activity. Our results demonstrate the importance of a complex study of physicochemical and biological soil parameters when investigating the impact of forest management on soil by, for example, providing data for the development of forest condition monitoring activities.
\end{abstract}

tree-soil interaction / soil acidification / microbial soil indicators

Kivonat - Fafajok erdőtalajra gyakorolt hatásának összehasonlítása fizikai, kémiai és biológiai talajtulajdonságok alapján. A fafajok és a talajképződés összefüggését vizsgáltuk az avarszintben és a 0-10 cm-es felső ásványi talajrétegben európai bükk (Fagus sylvatica), közönséges lucfenyő (Picea abies) és kocsánytalan tölgy (Quercus petraea) föfafajú erdőkben. Összehasonlítottuk a talaj fö kémiai, fizikai és egyes mikrobiológiai paramétereit, a mikrobiális biomasszát, az alap- és szubsztrátindukált légzést, lipid-foszfát tartalmat, foszfo-lipid zsírsav profilokat (PLFA) és a respirációs kinonokat (RQ). A talaj $\mathrm{pH}$, az agyag- és iszap\% szignifikánsan alacsonyabb volt, a kicserélhetö savasság magasabb volt a lucfenyő esetében, ami a kicserélhető kationok nagymértékủ kimosódását mutatja a felső talajrétegben, alacsony bázistelítettséget eredményezve. A mikrobiális metabolikus aktivitás és a mikrobiális biomassza értéke a lomblevelü erdők talajában szignifikánsan magasabb volt. A respirációs kvóciens (q) értéke a legmagasabb a lucfenyő alatt volt, a mikrobiális lebontás kedvezőtlen feltételeire utalva. Eredményeink bizonyítják a fiziko-kémiai és biológiai talajparaméterek komplex vizsgálatának fontosságát az erdőgazdálkodás talajra gyakorolt hatásának vizsgálatában, adatokat szolgáltatva például az erdőállapot-monitoring tevékenységek fejlesztéséhez.

fa-talaj kölcsönhatás / talajsavanyodás / mikrobiális talajparaméterek

* Corresponding author: heilbalint2@gmail.com; H-9400 SOPRON, Bajcsy-Zs. u. 4, Hungary 


\section{INTRODUCTION}

Climate change and forest management impacts present severe challenges for forestry. The decline in vitality of important tree species such as Norway spruce has accelerated in recent decades (Mátyás et al. 2010). Site conditions essentially limit the range of tree species used in forestry. Climate, hydrology, and soil together determine the development of the soil-plant system. Expected climate change induced shifts of forest communities will also be linked to soil indicators, emphasizing the importance of the interaction between tree species composition and soil indicators (Führer et al. 2010, Bartha et al. 2018).

Slowing microbial degradation processes can disrupt forest ecosystems with severelyreduced buffer capacities caused by (partly anthropogenic) acidification and nutrient cycles $(\mathrm{Ca}, \mathrm{Mg}$, and $\mathrm{K})$. This leads to a gradual loss of biodiversity, which can lead to the reduction of several important ecosystem processes in the soil (Borken - Brumme 1997).

Katayouan and Kooch (2019) compared four different forest types with respect to the effects of tree species composition on nutrient-cycling and soil-related processes. Their results proved that changes in litter quality had subsequent negative effects on soil fertility, as described by physicochemical and biological soil indicators, thereby emphasizing the importance of soil quality maintenance in silviculture.

Recognizing the factors that influence soil microbial communities is important for understanding how human activities, such as forest management and tree species selection, may impact ecosystem functioning (Bahnmann et al. 2018). Numerous methods to assess biological processes in soils exist. Oxygen-based respiration is a common way to measure the metabolic activity of microbes. This measurement effectively quantifies the respiratory activity of microbes living in soils (Anderson - Domsch 1978, Dilly 2003). In situ measurements of the biochemical determination of microbial cell components (e.g. phospholipids) can determine the microbial biomass. The structure of the microbial community is also of great importance: analysis of specific biochemical cell components, the so-called signature molecules, can provide important information (Hiraishi 1999, Kandeler 2007, da Costa et al. 2011, Birgander et al. 2014).

Our former site investigations around the research area in the Sopron Mountains revealed that high litter accumulation, surface soil acidity, and the presence of a leached upper Ehorizon was connected to spruce monoculture forest stands. These findings suggest that replacing ancient broadleaved species with conifers can affect the physicochemical and biological soil properties of the upper layers.

Our case study investigated the roles of three different forest types including European beech (Fagus sylvatica), sessile oak (Quercus robur), and Norway spruce (Picea abies) on an $\mathrm{O}$ and $\mathrm{A}$ horizon quality, described by physicochemical and biological indicators. Under natural conditions in Hungary, these tree species often compete with each other to occupy sites. The currently unfavourable ecological conditions for spruce are deteriorating further due to climate change. In addition, the expected processes are also endangering the living conditions of beech. That is why it is crucial to study the forest-scale replacement of one tree species for another and how these species replacements interact with soil processes and nutrient cycles.

We hypothesized that Norway spruce forest cover is less favourable for soil biological activity than broadleaved tree species forests are, and that this results in differences of soil biological activity. Our objectives were, therefore, to find and assess soil physicochemical and biological indicator differences between conifer and broadleaved stands. 


\section{MATERIALS AND METHODS}

\subsection{Study area}

The chosen study areas were a European beech (Fagus sylvatica L.; 41 years old; Lat: 47³9'19.7"N; Lon: 16²7'16.9"E, Sopron 171/G forest comp.) stand, a Norway spruce (Picea abies L.; 54 years old; 47³9'26.1"N; 16²7'16.1"E, Sopron 171/F forest comp.) stand, and a sessile oak (Quercus petrea Liebl.; 46 years old; 47³9'33.4"N; 16²8'14.3"E, Sopron 163/D forest comp.) stand in the Sopron Mountains near the Hungarian-Austrian border. The region is located in the warm temperate forest zone (yearly average temperature 9.5-9.8 ${ }^{\circ} \mathrm{C}$ ), and is dominated by deciduous broadleaf tree species. Elevation is between $500-550 \mathrm{~m}$; average yearly precipitation is about $800-850 \mathrm{~mm}$. The yield classes of all three stands are similar, measured as 4 (on a scale with decreasing quality from 1 towards 6).

According to the Hungarian forest climate classification, the climate of the area is beech because the 50-year (1961-2010) average of the Forestry Aridity Index (FAI) interpolated to the area is 3.65, which is the typical value of a beech climate, i.e. 3.5 and 4.75 (Führer 2010, Führer et al. 2011). Conditions below an FAI value of 3.5 are more favourable for spruce and those above an FAI value of 4.75 are more favourable for sessile oak. Further description of the area is provided by Gribovszki et al. (2006).

Parent material is unclassified tertiary (Miocene) fluvial sediment, on which a loamy soil containing coarse gravel formed. The soils in all three sampling areas belong to the WRB soil reference group cutanic luvisols and possess similar basic reference group properties.

\subsection{Sampling and measurements}

A soil pit was opened in all three stands and soil samples in 6 replicates were taken from each horizon respectively. These replicates were immediately transported to laboratory for storage at $4{ }^{\circ} \mathrm{C}$ until analysis. Soil microbial investigations were completed for litter samples and mineral soil samples from $0-10 \mathrm{~cm}$ depth. Laboratory analyses of physical and chemical soil characteristics were measured according to the Hungarian standards (MSZ-08-0205-2: 1978; MSZ-08-0206-2: 1978; MSZ-08-0215: 1978; MSZ-08-0452: 1980; MSZ-08-0480-2: 1982), summarized by Buzás et al. (1993). Soil microbial investigations: soil and litter samples were divided into subsamples to perform parallel microbial activity and microbial biomass measurements.

Microbial metabolic activity: the mineralization rate of dead organic matter accumulated at soil surface (litter layer and $0-10 \mathrm{~cm}$ layer of the mineral soil) was determined with 6 replicate measurements via the "basal respiration" (BAS) method (Heilmann - Beese 1992).

Microbial biomass:

a) Substrate-induced respiration (SIR) method SIR tests were conducted in 6 replicates of soil samples from each stand to determine the microbial biomass. The SIR tests were performed according to the modified method of Anderson - Domsch (1978) as described by Heilmann - Beese (1992). From the basal respiration and the microbial biomass, the respiratory quotient (q) was calculated as a simple quotient. This value provides information on the effectiveness of the decay.

b) Lipid phosphate measurements: Soil samples taken from the 0-10 $\mathrm{cm}$ mineral soil layer were placed into a Bligh and Dyer's solution (Bligh - Dyer 1959) in sterilized glass jars, and cooled and stored at $-20{ }^{\circ} \mathrm{C}$ until processed. Further processing included the chemotaxonomic measurements completed by the modified method of Findlay by Tóth et al. (2004).

Respiratory quotient (q-CO $\mathrm{CO}_{2}$ ): From the basal respiration and the microbial biomass, the respiratory quotient (q) was calculated as a simple quotient of basal respiration divided by 
microbial biomass. This value provides information on the effectiveness of the decay (Dilly, 2003).

Comparison of microbial communities: Cultivation independent chemotaxonomic methods were applied to study microbial communities.

Examination of the respiratory quinones (RQ): The organic components cleaned from mineral soil particles were evaporated under vacuum, and the lipid soluble materials (PLFA and RQ) were solved with chloroform. A silica-based octadecyl column was employed to separate lipid soluble components. The purification of the chloroform fraction containing quinones was performed with thin-layer silica gel. High pressure liquid chromatography was used for the instrumental analyses of the purified filtrate of quinones. Detection is based on specific light absorption observed at 270-nm wavelength. Test samples were compared with quinone profiles of pure cultures of bacterial strains.

Determination of phospholipid fatty acids (PLFA): Glyco-and phospholipids were washed from the chromatographic column using acetone and methanol, respectively. The methanol-phase was - likely to the preceding - concentrated in vacuum evaporation at $37^{\circ} \mathrm{C}$. The dried phospholipid content was dissolved in $0.5 \mathrm{ml}$ methanol: toluol (1:1) mixture. After separation of the two phases, the fatty acid analysis was performed by gas chromatograph (Tóth et al. 2004).

\subsection{Statistical analysis}

For data analysis, we used standard statistical tools (Statistica and Syntax 2000 statistical programs): quantitative data of physicochemical and microbial soil indicators were expressed with mean values and standard deviation. Paired sample t-tests were applied to compare physical and chemical soil indicators. Principal component analysis was used to describe the microbial community differences in the studied stands via chemotaxonomic markers (PLFA and RQ). Differences were considered significant at $\mathrm{P}<0.05$.

\section{RESULTS AND DISCUSSION}

\subsection{Soil physical and chemical indicators}

The mean values of physicochemical test results of the upper $0-10 \mathrm{~cm}$ mineral soil layer of the three forest stands are shown in Table 1.

Soil $p H\left(\mathrm{H}_{2} \mathrm{O}\right)$ and exchangeable acidity values $\left(\mathrm{y}_{2}\right)$ were significantly lower for spruce when compared to both deciduous stands, while hydrolytic acidity values $\left(\mathrm{y}_{1}\right)$ were significantly higher for spruce only in comparison to oak.

In reaction to the alkaline hydrolysis (in case of $\mathrm{y}_{1}$ ), all three stands soil colloids showed an acidic-highly acidic nature. For soils - under agricultural use - having hydrolytic acidity values $\left(\mathrm{y}_{1}\right)$ greater than 8 , liming is classified as unconditional (Buzás et al. 1993).

Humus- and nitrogen contents were significantly higher under sessile oak, compared to the other stands. The nitrogen content of the oak forest's soil was medium, and the other two had a low nitrogen supply. In contrast, plant-available phosphorus and potassium were both lowest in the soil of the spruce stand.

The Carbon/nitrogen ratio of soil organic matter was 18, 15, and 14 for oak, beech and spruce, respectively. All three values - which are favourable in terms of degradability - were lower than C/N values detected by Joergensen and Scheu (1999) in a beech and spruce forest in the Solling Mountains in Lower Saxony. Similar to their findings, the difference of C/N ratios between deciduous and coniferous stands was also small in our study. The $\mathrm{C} / \mathrm{N}$ rates are generally believed to be inversely proportional to the breakdown intensity, but some studies 
have shown that microbial degradation in forest soils cannot be described as a function of this single parameter, as other factors have an influence on their context (Spohn - Chodak 2015).

Table 1. Physical and chemical soil indicators in $0-10 \mathrm{~cm}$ depth of the mineral soil of three forest stands (Standard deviation in parentheses).

\begin{tabular}{|c|c|c|c|}
\hline Main tree species & Quercus robur & Fagus sylvatica & Picea abies \\
\hline $\mathrm{pH}\left(\mathrm{H}_{2} \mathrm{O}\right)$ & $4.9(0.18)$ & $4.6(0.11)$ & $4.3(0.08)$ \\
\hline $\mathrm{pH}(\mathrm{KCl})$ & $4.0(0.22)$ & $3.6(0.07)$ & $3.4(0.09)$ \\
\hline $\mathrm{y}_{1}$ (hydrolytic acidity) & $28(2.6)$ & $36(3.0)$ & $35(1.9)$ \\
\hline $\mathrm{y}_{2}$ (exchangeable acidity) & $3(1.4)$ & $9(1.0)$ & $13(0.6)$ \\
\hline Humus content $(\%)$ & $4.85(0.20)$ & $2.26(0.06)$ & $2.43(0.14)$ \\
\hline $\mathrm{N}_{\text {total }}(\%)$ & $0.16(0.02)$ & $0.09(0.02)$ & $0.10(0.03)$ \\
\hline $\mathrm{C} / \mathrm{N}$ & $18(1.15)$ & $15(3.98)$ & $14(5.79)$ \\
\hline AL-soluble $\mathrm{P}_{2} \mathrm{O}_{5}\left(\mathrm{mg} * 100 \mathrm{~g}^{-1}\right.$ d.s. $)$ & $13.2(2.32)$ & $22.5(3.08)$ & $11.4(2.34)$ \\
\hline AL-soluble $\mathrm{K}_{2} \mathrm{O}\left(\mathrm{mg} * 100 \mathrm{~g}^{-1}\right.$ d.s. $)$ & $16.1(2.48)$ & $19.8(2.32)$ & $9.9(1.83)$ \\
\hline $\begin{array}{l}\text { Cation Exchange Capacity = T-value } \\
\left(\mathrm{mmol} \mathrm{IE} * 100 \mathrm{~g}^{-1} \text { d.s. }\right)\end{array}$ & $30.0(3.16)$ & $41.5(3.33)$ & $39.3(3.72)$ \\
\hline $\begin{array}{l}\text { exchangeable } \mathrm{Ca}^{2+}, \mathrm{Mg}^{2+}, \mathrm{K}^{+} \text {és } \mathrm{Na}^{+}=\mathrm{S} \text {-value } \\
\left(\mathrm{mmol} \mathrm{IE}^{*} 100 \mathrm{~g}^{-1} \text { d.s.) }\right.\end{array}$ & $5.5(1.64)$ & $7.0(2.10)$ & $6.3(0.52)$ \\
\hline Base saturation $\%(\mathrm{~V} \%)$ & $18(6.6)$ & $17(4.29)$ & $16(1.63)$ \\
\hline hy\% (higroscopicity) & $1.99(0.09)$ & $2.04(0.18)$ & $1.83(0.24)$ \\
\hline $\mathrm{K}_{\mathrm{A}}$ (plasticity index acc. to Arany) & $54(3.25)$ & $55(3.95)$ & $50(2.80)$ \\
\hline 5 hours capillary rise $(\mathrm{mm})$ & $150(7.73)$ & $113(9.68)$ & $141(5.56)$ \\
\hline \multicolumn{4}{|l|}{ Particle size distribution } \\
\hline Sceletts $(>2 \mathrm{~mm}) \%$ & $0(0)$ & $0(0)$ & $0(0)$ \\
\hline $\mathrm{cS} \% \quad$ (coarse Sand\% 2-0.2 mm) & $31(2.79)$ & $24(5.35)$ & $21(5.13)$ \\
\hline $\mathrm{fS} \% \quad$ (fine Sand $\%$ 0.2-0.02 mm) & $23(3.37)$ & $33(2.94)$ & $54(2.59)$ \\
\hline $\mathrm{Si} \% \quad($ Silt\% $0.02-0.002 \mathrm{~mm})$ & $26(3.13)$ & $21(3.01)$ & $7(2.07)$ \\
\hline CL\% $\quad($ clay\% $<0.002 \mathrm{~mm})$ & $20(5.61)$ & $22(6.02)$ & $18(4.76)$ \\
\hline
\end{tabular}

Total adsorption capacity of the soil (T-value according to the modified method of Mehlich MSZ-08-0215: $1978=\mathrm{CEC}_{\mathrm{t}}$ ) was lowest in the oak forest soil; slightly higher quantities were obtained under spruce and beech. The latter two are average values found in Cutanic Luvisol soils in Hungary, but the value under oak is below average.

$S$-values (sum of "basic" or "alkaline forming" cation in Eq according to the modified method of Mehlich) and $V$-values (base saturation in \%) all displayed low base saturation for oak, beech, and spruce respectively. This indicates that negative surface charges of soil particles are mostly neutralized with $\mathrm{Al}^{3+}$ and $\mathrm{H}^{+}$ions. Even if differences were not significant, the soil of the spruce stand once again had the most unfavourable properties $(\mathrm{V}=15 \%)$, increasing the risk of clay-mineral destruction with negative effects on nutrient and hydrological cycles of the ecosystem.

The oak and beech forest soils had a loamy texture according to the particle size distribution $(\mathrm{Si}+\mathrm{Cl}=46 \%, 43 \%$ ) (Table 1), while the texture of the spruce stand is a poorer $(\mathrm{Si}+\mathrm{Cl}=25 \%)$ sandy or sandy loam texture, which could possibly indicate the removal of clay from this horizon, resulting in a weaker expression of structure, reduced pore space, and water holding capacity of the upper mineral soil over a longer term. Nevertheless, this would need to be proved by an additional texture analyses of underlying B-horizons.

\subsection{Soil biological indicators}


The results of metabolic activity measurements are shown in Figure 1. Microbial respiration intensity of the beech litter was the highest. The basal respiration of spruce litter was significantly $(p=0.05)$ less. Values of oak leaf litter did not differ significantly from that of the other two stands.

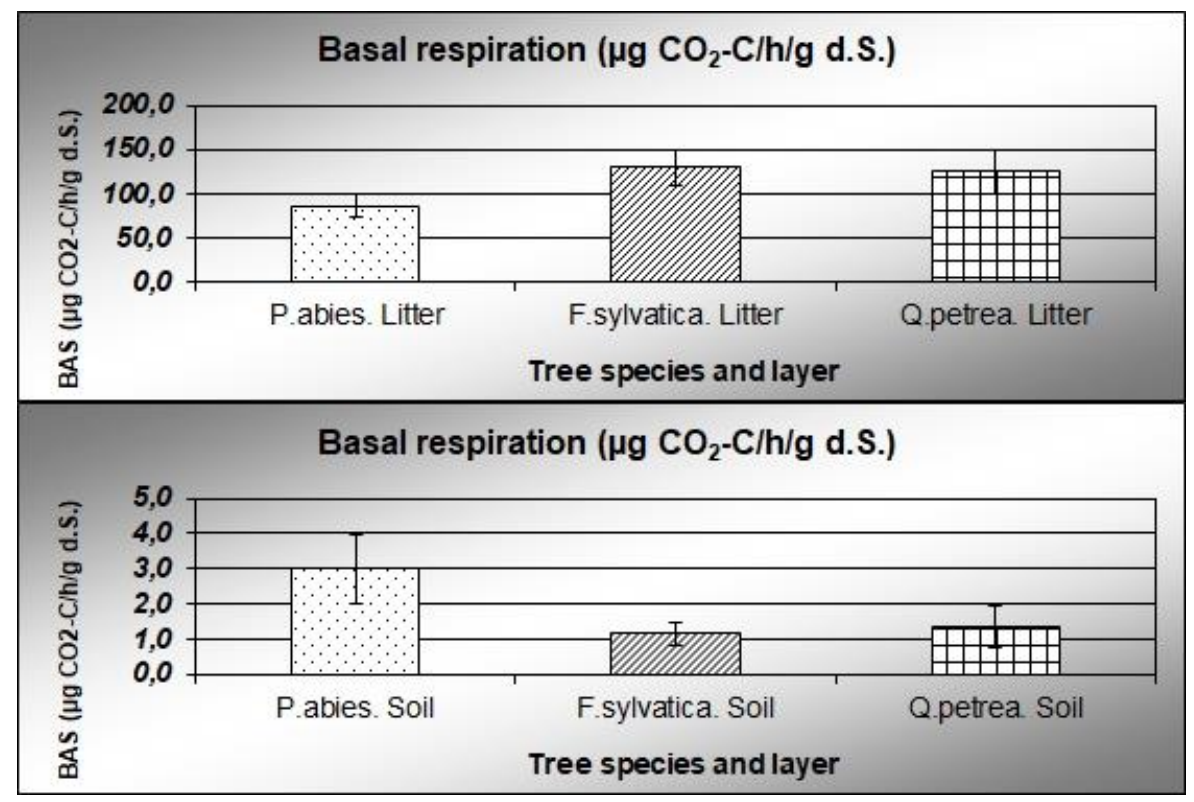

Figure 1. Basal respiration (with standard deviation) in the litter and the $0-10 \mathrm{~cm}$ mineral soil layers in the spruce ( $P$. abies), beech ( $F$. sylvatica) and sessile oak ( $Q$. petrea) forests

We detected a reversed situation regarding the microbial respiration of the uppermost 0-10 cm mineral soil layer: soil carbon mineralization was highest under spruce. The two deciduous stands did not differ from each other in this respect.

Microbial biomass from substrate induced respiration (SIR): the SIR-value was lowest under spruce (Figure 2), while microbial biomass stocks were more than twice as high in deciduous leaf litters. The highest microbial biomass in the mineral soil was found under spruce. The microbial carbon stock of the upper mineral soil layer of the beech forest was significantly lower. The value under oak is very similar to this, but due to the high standard deviation, it is not significantly different from the other two stands.

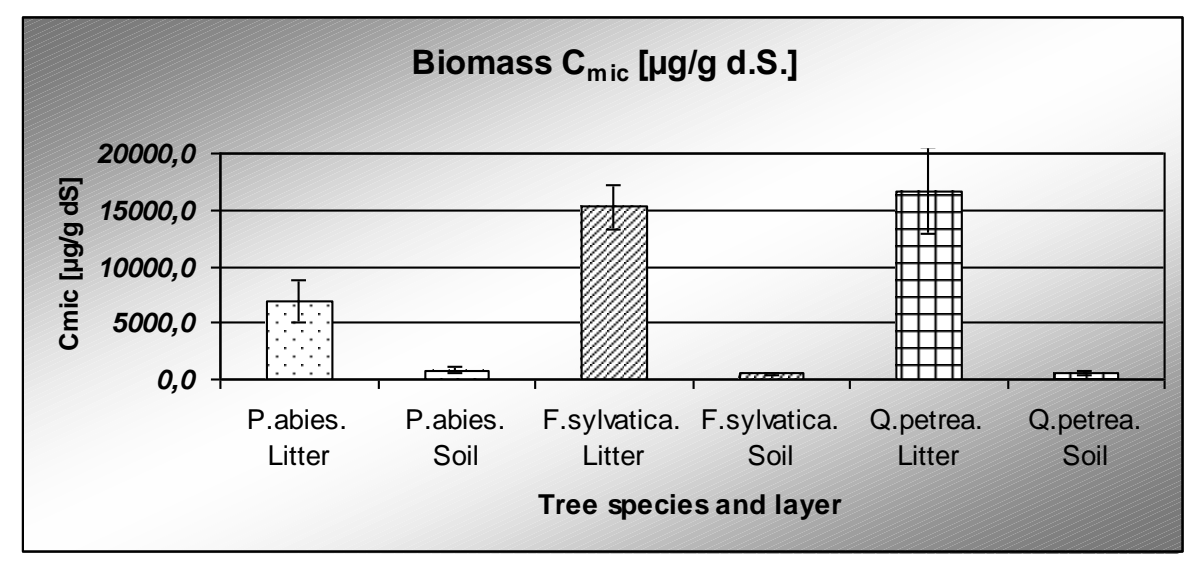

Figure 2. Microbial biomass $\left(C_{m i c}\right)$ (with standard deviation) measured with the SIR method in the litter and the 0-10 cm mineral soil layers in the spruce ( $P$. abies), beech ( $F$. sylvatica) and sessile oak $(Q$. petrea) forests 
In the end, the microbial biomass concentration found in the litter and upper mineral soil was largest in the oak forest. The concentration was only slightly smaller in the beech forest, but it was only half of the level under spruce.

Similar to microbial biomass values derived from SIR, according to lipid- $\mathrm{PO}_{4}$ measurements, the soil under spruce had the highest microbial biomass (Table 2.) and were roughly equally low in the soils of the two deciduous stands. Values found were only about $1 / 3$ of those measured with the SIR method.

Table 2. Microbial biomass calculated from the lipid phosphate content of the $0-10 \mathrm{~cm}$ mineral soil layer in the spruce (P. abies), beech $(F$. sylvatica) and sessile oak (Q. petrea)

\begin{tabular}{lccc}
\hline Forest stand & P. abies & F. sylvatica & Q. robur \\
\hline Microbial biomass $\mu \mathrm{g} \mathrm{C}_{\text {mic }} * \mathrm{~g}^{-1}$ d.s. & 291 & 166 & 157 \\
\hline
\end{tabular}

The respiratory quotient for each of the three stands is significantly lower in the mineral soil than in the leaf litter (Figure 3). The value of both layers of spruce was significantly higher compared to the deciduous stands.

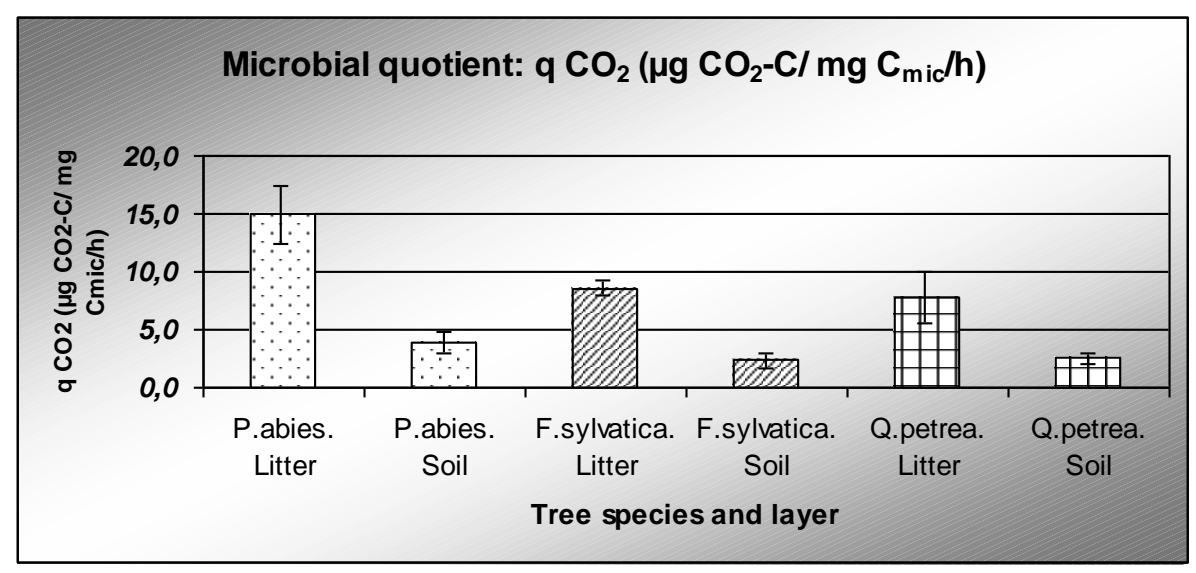

Figure 3. Respiratory quotient $\left(q-\mathrm{CO}_{2}\right)$ (with standard deviation) in the litter and the $0-10 \mathrm{~cm}$ mineral soil layers in the spruce ( $P$. abies), beech ( $F$. sylvatica) and sessile oak ( $Q$. petrea) forests

In the soil microbial community investigations, the fatty acid patterns of each sample contained compound (C16: 0, C14: 0, Q10), which can be found in a wide range of microbes. In all samples, the highest amounts found were of plant fatty acids (C18:1 t9c11, C18: 2 c9-12) and of the very common Q-10 molecules (main or secondary quinones of numerous bacteria, occurring in the mitochondria of many eukaryotic cells, in plants and protists as well). MK-7 occurred in all three stands, branched iso-, anteiso-, 16-19 carbon atoms containing fatty acids, these compounds formed the dominant fraction of the compounds in each case.

Compounds characteristic for micro-fungi occurred in larger quantities $\left(\mathrm{Q}-11 \mathrm{H}_{2}, \mathrm{Q}-10 \mathrm{H}_{2}\right)$; these did not emerge in the beech stand under oak and under spruce. In addition, these samples contained higher amounts of poly-unsaturated menaquinones (MK10H4, MK10H6). C20:2 and C22:3 fatty acids were also found.

Figure 4 illustrates the differences of soil chemotaxonomic markers between the upper soil layers of the three forests. Those components occurred in each sample and, in order to prevent interference with the variance of the samples, are not included in the figure.

The principal component analysis of soil samples from three forest stands brought a clear separation of the stands (figure not shown). The soil of the spruce forest differed most from the deciduous stands with regard to its soil microbial characteristics. More specifically, the 
lower BAS, the lower SIR and lipid-phosphate derived microbial biomass as well as the highest RQ brought a statistically clear separation for spruce.

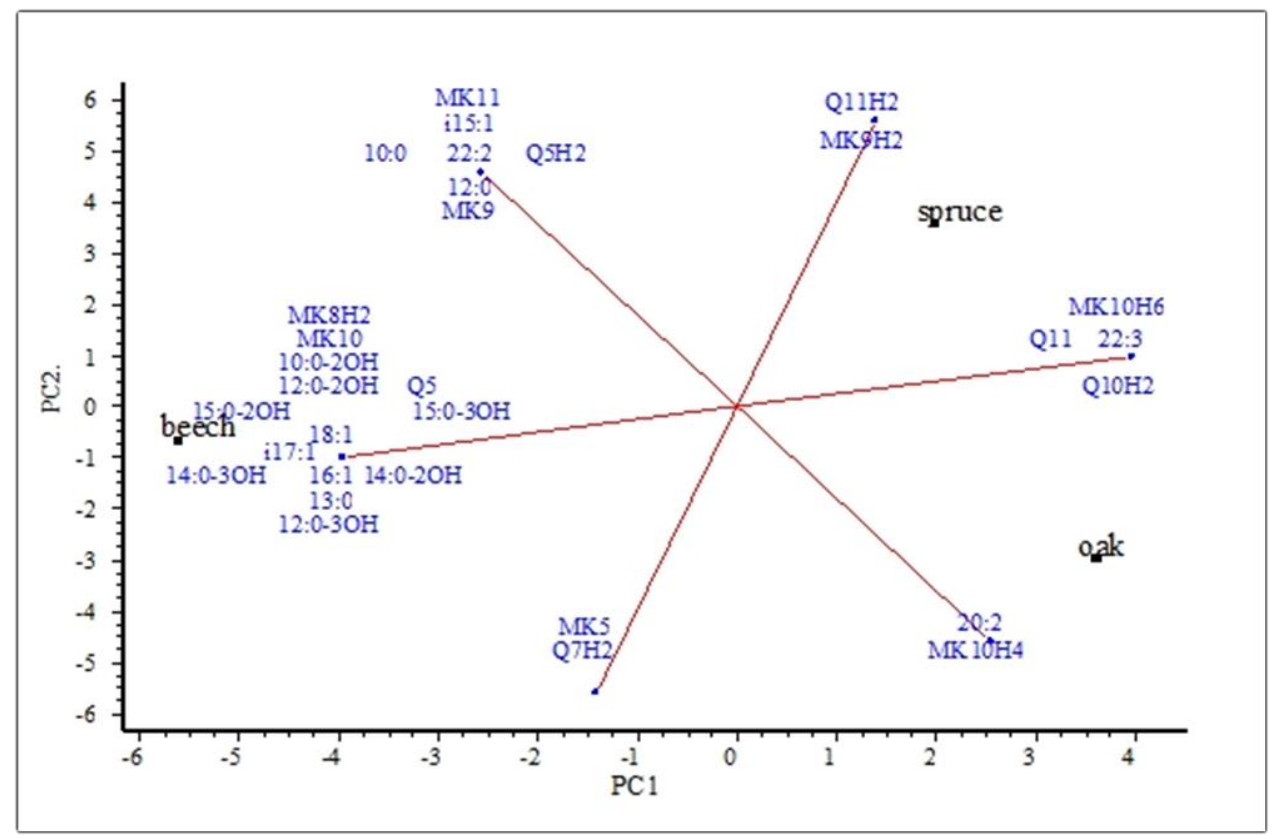

Figure 4. Main component analyses of the microbial communities described by chemotaxonomical markers (PLFA and RQ) in the spruce (P. abies), beech (F. sylvatica) and sessile oak (Q. petrea) forests soils

The abovementioned results indicate that acidification of the upper soil was greatest in the coniferous stand. Considering the highly acidic range and the high level of hidden-acidity, inherent small differences in $\mathrm{pH}$ can seriously impact the flora and fauna of the ecosystems, as observed with $\mathrm{pH}<4.2$ for soil biota by Mössmer (2001), or as described in a long term study by Oulehle et al. (2007).

Forest stands usually need to restore mineral phosphorus daily because the plants can completely take up the available amount in a short time. The different order in comparison of humus contents vs. readily available phosphorus is partly justified by the slightly more intense microbial degradation measured in the beech forest, as suggested by BAS values.

Based on the concentrations of soil organic matter and, thus, the important macronutrients, oak and beech stands experienced more favourable conditions than the spruce forest. Lower soil $\mathrm{pH}$-values and low availability of nutrients may result in reduced plant biomass production, assuming slower microbial turnover by spruce (Gisi 1990; Blume et al. 2016).

As expected, beech and oak litter proved to be more easily biodegradable than spruce needles (Gencsi - Vancsura, 1997). However, the accumulation of a thick layer of spruce needles has not yet been found, likely due to the short history of the conifer stands at the site. Although we expected lower microbial metabolic activity in the upper mineral soil under spruce, results showed an opposite trend, with lower metabolic activity in the deciduous stands. On one hand, it must be noted that the level of metabolic activity in the mineral soil of all stands was almost two orders of magnitude smaller than measured in the litter layer, which still indicates that decay of organic matter is altogether faster in the deciduous stands overall. The more intense breakdown in the upper mineral soil of the mostly acidic soil under spruce can perhaps find its causes in the slower transformation taking place in the litter layer, which leads to a higher transport of weakly transformed, easily degradable compounds to the upper mineral soil layer. This could be also indicated by the closest $\mathrm{C} / \mathrm{N}$ ratio under spruce as well. 
Similar results were found in the literature. Joergensen and Scheu (1999) studied soil chemical and microbial gradients with depth under beech and spruce forests.

Microbial biomass values delivered from SIR were very high according to the data recorded in Dilly (2003). This is probably the result of the less intense soil acidification and the higher average temperatures of the Sopron sites. A comparison of data to a Hungarian study (Molnár et al. 2016) on arable land proved our values to be higher, probably as forest litter remains on soil surface as opposed to the annual removal of biomass in agriculture.

Similar to decay activity, microbial biomass was much smaller in the mineral soil compared to the litter in all three forests respectively. A slight shift of microbial decay from the litter layer to upper mineral soil is again indicated in the case of spruce with high microbial stocks at the upper $10 \mathrm{~cm}$ of the mineral soil. Our data matches those in Raubuch and Beese (1999), who found a clearly marked gradient down from fresh litter throughout to mineral B horizon regarding microbial biomass and the SIR- $\mathrm{C}_{\mathrm{mic}}$.

The metabolic quotient (q) was higher for spruce both for the litter and the mineral soil layer. Scheu and Parkinson (1994) studied the microbial biomass, BAS, RQ, and $\mathrm{C}_{\text {mic }} / \mathrm{C}_{\text {org }}$ ratios in different soil layers of a poplar and of a pine forest in Alberta, Canada. The q-ratio decreased strongly with increasing soil depth, from which the authors concluded that the use of the carbon content of the substrate by microorganisms (i.e. assimilation!) becomes more efficient at the later stages of decomposition in both types of forests.

Similar to findings of Djajakirana et al. (1996), our PLFA results showed a higher proportion of fungi in the microbial communities under spruce than in the deciduous stands. A higher RQ experienced in the litter and in the mineral soil of spruce indicates that the fungal/bacterial ratios are increased with progressing soil acidification, while the carbon originating from available organic material sources can be assimilated less efficiently by the microbes. This results in higher proportions of $\mathrm{CO}_{2}$ released during decay of the same amount of organic compounds. This assumption could be controlled with the use of the selective inhibition method.

Lower biomass values derived from lipid-phosphate are probably explained by the increased number of active microbes after the addition of glucose in the SIR method. However, there was a good correlation of microbial biomass values in terms of comparison of the three forest stands.

It should be also noted that the results of the PLFA analysis detected a large amount of plant-characteristic compounds, so the lipid phosphate biomass values may not only characterize the microbial biomass, but are also influenced by the remains of fine roots in the soil samples. Consequently, these results should be treated with some reservations.

The above-described biological indicators confirm that the microbial processes suffer inhibition in the mostly acidified forest soil under spruce and even the effectiveness of microbial metabolism was reduced.

Among the chemical characteristics of the soil, highest latent acidity ( $\mathrm{y}_{2}$-value), and the lowest clay+silt contents separate the soil under spruce statistically again. The deciduous beech and oak stands showed higher mean values of $\mathrm{pH}$, higher nutrient contents and base saturation as well as higher proportions of fine particles, indicating more stable soil structures. These results are consistent with the phenomenon described in literature, that deciduous stands tend to build in higher amounts of the so-called "basic" or "alkaline forming" cations, repeatedly resulting in higher proportions of these cations in their litter, which then get incorporated into the humus compounds of the upper mineral soil (Blume et al. 2016).

More favourable soil chemical and physical characteristics lead to better overall nutrient and hydrological cycling. Also, metabolic activity values and microbial biomass values are higher, and the breakdown is more efficient in the deciduous stands than it is in coniferous stands. 
Similar correlations were shown by Bååth and Anderson (2003) who studied 53 deciduous forests soils for soil fungal/bacterial ratios in the microbial biomass, combining the SIR method with the selective inhibition of respiration (SI) technique. Strong linear correlation was found between the total microbial biomass calculated from the SIR- and PLFA-methods. Both biomass values were positively correlated with soil $\mathrm{pH}$. The fungal/bacterial ratio value specified with selective inhibition was significantly decreased with increasing soil $\mathrm{pH}$.

Several compounds found in our samples can be characteristic of a wide range of microbes, some for plants and others only generally for bacterial and plant mitochondria. These had little taxonomic value for our study. Nonetheless, it is not surprising to find these compounds in large quantities in forest soils.

Similarly, compounds specific for common Gram-positive soil bacteria - e.g. Bacillus, Agromyces, Actinomyces, Aureobacterium genus (MK-7, branched iso-, anteiso fatty acids with 16-19 carbon atoms) - were found. These formed the dominant faction in all three soils.

Chemotaxonomic markers separate the beech forest soil clearly. On the one hand, this is due to the presence of large amounts of short-chain hydroxy-fatty acids, which are mainly characteristic for lipopolysaccharide layers in Gram-negative bacteria. The diversity of these compounds is conspicuous in the soil of the beech stand, and some are even specific for a narrower range of taxa, e.g. C12:0-2OH - Alcaligenes, Chitinomonas; C14:0 -Alcaligenes, C15:0-2OH - Burkholderia.

Gram-negative soil bacteria belong to a diverse, wide range of multiple bacterial genera, which are often heterotrophic, breaking down their carbon sources by respiration or fermentation. Among these chemoautotrophic bacteria (e.g. Nitrosomonas, Nitrobacter, Thiobacillus), there are those for which the source of carbon is atmospheric $\mathrm{CO}_{2}$. Their total absence in the soil of oak and spruce is unlikely, but their presence may be "masked" by other common compounds.

The Q-5 compound appeared only in the beech soil. Although we do not consider it as a main quinone of any bacteria, it is a secondary quinone in a number of Gram-negative, facultative anaerobic organisms (e.g. Escherichia, Klebsiella, Proteus, Aeromonas genera). Some of these can carry out very intense mineralisation ("rot") even in the absence of $\mathrm{O}_{2}$, without producing harmful by-products.

The $K$. pneumoniae found here is a common nitrogen fixing representative of this genus. Species of Aeromonas are capable of butylene glycol fermentation, while species of the Proteus genus mix with acidic fermentations. These organisms are largely not soil bacteria; however, it is conceivable that they could have found their way into the soil via animal faeces. Otherwise, members of the Enterobacteriaceae family cannot survive long in this environment.

The C18:1 fatty acid appears also only under beech. Besides plants, this may be characteristic for mycorrhizae as well. Iso branched $\mathrm{C} 17: 1$ and $\mathrm{C} 15: 1$ fatty acids are characteristic markers of Cytophaga genus and of some sulphate-reducing bacteria. The largest amount of the MK5 compound, which is specific as a main-chinone for Capnocytophaga species and as a side-chinone for Flavobacterium, was found in the soil of the beech stand. These are typical residents of root surfaces of various plants.

Other compounds were detected in the soil of the beech stand: MK-9, MK-10, MK-11 can be at first quinones of some common soil bacteria (Agrobacterium, Aureobacterium, Rathayibacter, etc.). On the other hand, these act as main- and secondary quinones of the Bacteroides genus. The presence of the Bacteroides genus is probable. Other fatty acids characteristically found in anaerobic bacteria were detected in addition to these quinones. The species of the genus Bacteroides - together with other anaerobes (e.g. Clostridium) - are characterized by their role in causing "soil sickness" in badly aerated soils. 
Compounds specific for microfungi were found in soil samples from the oak stand, and even more typically, in the samples from the spruce stand. Besides these, we found greater quantities of polyunsaturated menaquinones $\left(\mathrm{MK}^{10 \mathrm{H}_{4}}, \mathrm{MK} 10 \mathrm{H}_{6}\right)$ in both soils, which suggests the presence of Actinobacteria, a very common group of Gram-positive bacteria living in soils. In terms of their metabolism, Actinobacteria are obligate aerobic saprophytes, and comprise an average of about $1-10 \%$ of the total soil bacterial population. They are completely absent in the litter layer and usually have their largest numbers in 5-10 cm depth of the mineral soil. They grow on multicomponent substrates, attack mostly hardlydegradable materials, like lignin, chitin, and starch. Several Actinobacteria (specifically Streptomyces species) produce antibiotics such as streptomycin, chloramphenicol, or tetracycline, and they are partly responsible for the typical scent of the soil, which is due to the release of gaseous Terpent derivates (e.g. geosmin) due Gisi (1990).

In the same samples, the C20:2 and C22:3 compounds suggest the presence of protozoa and cyanobacteria. In the soil, these spend the active phase of their lives in the water-filled soil pores and in surface water films on soil particles and roots.

Regarding the physical and chemical indicators as well as microbial activity and biomass patterns, the results of the microbial community investigations show a different distribution of the three forest stands. While soil acidification under spruce resulted in more unfavourable conditions compared to those of the nearly similar deciduous forests soils, the microbial community compositions were closer to each other in the spruce and the oak stands, and we saw a more distinct, specific microbial soil community under beech. This separation of beech originated partly from the presence of microbes, suggesting anaerobic conditions (facultative and obligate anaerobes) compared with the aerobic conditions indicating microbes of the other two forest soils. A reason for this could be the close parallel layering of the beach litter leaves, which, in contrast to spruce needles and curvy oak leaves, seal the soil surface during precipitation.

Microorganism are critical in mediating $\mathrm{C}$ - and N-turnover in soils. Yet, a recent study (Zheng et al. 2019) has shown that soil-C processes were only directly affected by the soil environment, but not affected by microbial community composition. In contrast, soil-N processes were significantly related to bacterial/archaeal community composition and bacterial/archaeal/fungal richness/diversity, but not directly affected by the soil environment.

All of this demonstrates that the ecological assessment of forest soils should never be conducted solely by physical-chemical characterization. It is equally important to perform additional microbiological studies, and vice versa.

Acknowledgements: This work was supported by EFOP-3.6.1-16-2016-00018 project of the University of Sopron.

\section{REFERENCES}

ANDERSON, J.P.E. - DOMSCH K.H. (1978): A physiological method for the quantitative measurement of microbial biomass in soils. Soil Biol. Biochem. 10: 215-221.

https://doi.org/10.1016/0038-0717(78)90099-8

Bahnmann, B. - Masinová, T. - Halvorsen, R. - DAvey, M.L. - Sedlák, P. - ToMsovsky, M. BALDRIAN, P. (2018): Effects of oak, beech and spruce on the distribution and community structure of fungi in litter and soils across a temperate forest. Soil Biology and Biochemistry 119: 162-173. https://doi.org/10.1016/j.soilbio.2018.01.021

Bartha, A. - Berki, I. - LengYel, A. - RAszTovits, E. - TiborCZ, V. - ZAgYVAI, G. (2018): Erdőtársulások és fafajaik átrendeződési lehetőségei a változó klímában. [Estimated shifts of 
forest communities and tree species during changing climate]. Erdészettudományi Közlemények 8 (1): 163-195. https://doi.org/10.17164/EK.2018.011 (in Hungarian)

BÅÅT, E. - ANDERSON, T.H. (2003): Comparison of soil fungal/bacterial ratios in a $\mathrm{pH}$ gradient using physiological and PLFA-based techniques. Soil Biol. Biochem. 35: 955-963. https://doi.org/10.1016/S0038-0717(03)00154-8

BirgANDER, J. - ROUSK, J. - OlSSON, P.A. (2014): Comparison of fertility and seasonal effects on grassland microbial communities. Soil Biol. Biochem. 76: 80-89. https://doi.org/10.1016/j.soilbio.2014.05.007

BLIGH, E.G. - DYER, W.J. (1959): A rapid method of total lipid extraction and purification. Can. J. Biochem. Physiol. 31: 911-917. https://doi.org/10.1139/059-099

Blume, H-P. - BrÜMmer, G.W. - Fleige, H. - Horn, R. - KANDEler, E. - Kögel-KNaber, I. KRETZSCHMAR, R. - STAHR, K. - WILKE, B.M. (2016): Scheffer/Schachtschabel - Soil Science. Springer Verlag, Berlin. ISBN 13: 978-3642309410

BORKEN, W. - BRUMME, R. (1997): Liming practice in temperate forest ecosystems and the effects on CO2, N2O and CH4 fluxes. Soil Use Manage. 13: 251-257. https://doi.org/10.1111/j.1475-2743.1997.tb00596.x

BuZÁS, I. - DARÓCZI, S. - DÓDONY, I. - KÁlmÁN, A. - KoCSIS, I. - PÁRTAY, G. - RAJKAi, K. RÓzSAVÖlgYI, J. - STEFANOVITS, P. - SzILI-KOVÁCS, T. - SzÜCS, L. - VÁRALlYAI, GY. (1993): Talaj- és Agrokémiai vizsgálati módszerkönyv 1-2. [Methods of soil- and agrochemical studies 12]. INDA 4231 Publisher, Budapest. Pp. 90-116; 165-169; 188; 200; 202-203. (in Hungarian)

Da Costa, M.S. - Albuquerque, L. - Nobre, M.F. - Wait, R. (2011): The extraction and identification of respiratory lipoquinones of prokaryotes and their use in taxonomy. Method Microbiol. 38: 197-206. https://doi.org/10.1016/B978-0-12-387730-7.00009-7

DILlY, O. (2003): Bodenkundliches Laborpraktikum am Institut für Pflanzenernährung und Bodenkunde der Universität Kiel WS 1998/99. Universität Kiel.

DJAJAKIRANA, G. - Joergensen, R.G. - MeYer, B. (1996): Ergosterol and microbial biomass relationship in soil. Biol. Fert. Soils. 22: 299-304. https://doi.org/10.1007/BF00334573

FÜHRER, E. (2010): A fák növekedése és a klíma [Tree growth and the climate]. Klíma-21 füzetek 61: 98-107. (in Hungarian) https://www.researchgate.net/publication/322293704_A_fak_novekedese_es_a_klima

FÜHRER, E. - HORVÁTH, L. - JAGODICS, A. - MACHON, A. - SZABADOS, I. (2011): Application of new aridity index in Hungarian forestry practice. Időjárás 115 (3): 205-216.

GENCSI, L. - VANCSURA, R. (1997): Dendrológia. [Dendrology] Mezőgazda Kiadó Budapest: pp. 125, 237, 221. (in Hungarian)

GISI, G. (1990): Bodenökologie. [Soil ecology] Georg Thieme Verlag Stuttgart - New York: pp. 4977, 152-178. (in German)

GribovsZKi, Z. - KALICZ, P. - KUCSARA, M. (2006): Streamflow characteristics of two forested catchments in the Sopron Hills. Acta Silv. Lign. Hung. 2: 81-92.

HeILMANN, B. - BEESE, F. (1992): Miniaturized method to measure carbon dioxide production and biomass of soil microorganisms. Soil Sci. Soc. A. J. 56: 596-598. https://doi.org/10.2136/sssaj1992.03615995005600020041x

HIRAISHI, A. (1999): Review: Isoprenoid quinones as biomarkers of microbial populations in the environment. J. Biosci. Bioeng. 88 (5): 449-460. https://doi.org/10.1016/S1389-1723(00)87658-6

JOERGENSEN, R.G. - SCHEU, S. (1999): Depth gradients of microbial and chemical properties in moder soils under beech and spruce. Pedobiologia 43: 134-144.

KANDELER, E. (2007): Physiological and biochemical methods for studying soil biota and their function. Soil Microbiology, Ecology and Biochemistry. 3rd ed. Elsevier, Darmstadt. Pages 53-83. https://doi.org/10.1007/s13593-013-0162-9

KATAYOUN, H. - KoOCH, Y. (2019): Effects of diversity of tree species on nutrient cycling and soilrelated processes. Catena 178: 335-344. https://doi.org/10.1016/j.catena.2019.03.041

MÁTYÁs, CS. - FÜHRER, E. - BERKI, I. - CSÓKA, GY. - DRÜSZLER, Á. - LAKATOS, F. (2010): Erdők a szárazsági határon. [Forest at the limit] Klíma-21 Füzetek 61: 84-97. University of Sopron, Sopron, Hungary. (in Hungarian) https://www.researchgate.net/publication/283257726_Erdok_a_szarazsagi_hataron 
MolnáR, E. - SzILI-KovÁCs, T. - VillánYI, I. - KNÁB, M. - KRistóF, K. - Heltai, G. (2016): $\mathrm{CO}_{2}$ efflux and microbial activities in undisturbed soil columns in different nitrogen management. Plant Soil Environ. 62 (9): 402-407. https://doi.org/10.17221/216/2016-PSE

MÖSSMER, E.M. (2001): Gesunde Böden braucht der Wald. Veröffentlichungen der Stiftung Wald im Not. [Th forests in need for healthy soils] 11: 18-23. (in German) https://waldkritik.de/wp-content/uploads/2015/03/WuB ges.pdf

OULEHLE, F. - HOFMEISTER, J. - HRUSKA, J. (2007): Modeling of the long-term effect of tree species (Norway spruce and European beech) on soil acidification in the Ore Mountains. Ecological Modelling 204 (3-4): 359-371. https://doi.org/10.1016/j.ecolmodel.2007.01.012

RAUBUCH, M. - BEESE, F. (1999): Comparison of microbial properties measured by $\mathrm{O}_{2}$ consumption and microcalorimetry as bioindicators in forest soils. Soil Biol. Biochem. 31: 949-956.

SCHEU, S. - PARKINSON, D. (1994): Changes in bacterial and fungal biomass-C, bacterial and fungal biovolume and ergosterol content after drying, remoistening and incubation of different layers of cool temperate forest soils. Soil Biol. Biochem. 26: 1515-1525. https://doi.org/10.1016/0038-0717(94)90093-0

SPOH, M. - CHODAK, M. (2015): Microbial respiration per unit biomass increases with carbon-tonutrient ratios in forest soils. Soil Biology and Biochemistry 81: 128-133. https://doi.org/10.1016/j.soilbio.2014.11.008

TótH, E.M. - TAUBER, T. - KovÁCS, H. - BOHUS, V. - BorSODI, A.K. - RÉVÉSZ, S. - MÁRIALIGETI, K. (2004): Evaluation of biodiversity by respiratory quinone (RQ) and phospholipid fatty acids (PLFA) analysis in different soils and sediments. In: CHROŇÁKOVÁ, A. - KRIŠTƯFEK, V. ElhottovÁ, D. - MALÝ, S. (eds).: In Proceedings of the 9th Methodological workshop „Present methods for investigation of microbial community biodiversity in soils and substrates". Institute of Soil Biology AS CR, České Budějovice.

https://www.researchgate.net/profile/Alica Chroakova/publication/40314557 Present methods f or_investigation_of_microbial_community_biodiversity_in_soils_and_substrates_9th_methodolo gical_workshop_Ceske_Budejovice_March_2004/links/5816fc8508ae90acb2410bab/Presentmethods-for-investigation-of-microbial-community-biodiversity-in-soils-and-substrates-9thmethodological-workshop-Ceske-Budejovice-March-2004.pdf\#page=31

Zheng, Q. - HU, Y. - Zhang, S. Noll, L. - Böckle, T. - DieTrich, M. - Herbold, C.W. EichORST, A. - WOEBKEN, D. - Richter, A. - WANEK, W. (2019): Soil multifunctionality is affected by the soil environment and by microbial community composition and diversity. Soil Biology and Biochemistry 136: 1-13. https://doi.org/10.1016/j.soilbio.2019.107521 
